\title{
STUDI LITERATUR KESEJAHTERAAN RUMAH TANGGA USAHA BUDIDAYA IKAN NILA DI KABUPATEN BENGKULU UTARA)
}

\author{
Fikri Islami ${ }^{1)}$, Yusnida) \\ ${ }^{1}$ Jurusan Ekonomi Pembangunan Fakultas Ekonomi Dan Bisnis Universitas Bengkulu \\ Email: fikriislami123@gmail.com \\ ${ }^{2}$ Jurusan Ekonomi Pembangunan Fakultas Ekonomi Dan Bisnis Universitas Bengkulu \\ Email: yusnida@unib.ac.id
}

\begin{abstract}
This study aims to determine the characteristics of tilapia farmers in Sido Luhur Village, determine the level of income and sources of income of tilapia cultivator households, and determine the level of welfare of tilapia cultivator households. The method used in this study is descriptive qualitative, which is the characteristics of tilapia fishers, namely age, number of dependents, education level, business experience, pool area, and labor needed. To measure the level of welfare of tilapia cultivator households using measurements from the Central Agency for household welfare criteria based on BKKBN. The results of measurements of the level of wellbeing in the community of Sido Luhur Village, Padang Jaya Subdistrict, North Bengkulu Regency can be said to be prosperous, this is because tilapia farmers in general have met the criteria according to BKKBN indicators, because most of them have been able to fulfill their basic daily needs, as many as 33 respondents, which are in the third prosperous stratum, and according to research there are more tilapia farmers who are in the pre-prosperous category.
\end{abstract}

Keywords: Hight of Welfare, Income

\section{PENDAHULUAN}

Pembangunan merupakan sebuah upaya atau proses untuk melakukan ke arah yang lebih baik. Proses pembangunan meliputi berbagai perubahan pada aspek sosial, politik, ekonomi, dan budaya. Oleh karena itu, pembangunan merupakan syarat mutlak bagi kelangsungan suatu Negara. Komponen dasar atau nilai inti keberhasilan pembangunan ekonomi antara lain kecukupan (sustenance), jati diri (self-esteem), kebebasan (freedom), merupakan tujuan pokok yang harus dicapai oleh setiap masyarakat (Todaro, 2006).

Proses pembangunan yang dilakukan di semua wilayah bertujuan untuk meningkatkan kesejahteraan penduduk. Kesejahteraan yang dimaksud tidak semata-mata diukur dari aspek tinggi atau rendahnya pendapatan per kapita maupun tingkat pertumbuhannya, tetapi juga menyangkut aspek penurunan tingkat kemiskinan dan pemerataan pendapatan yang diterima penduduk. Tingkat kemiskinan menjadi tolak ukur utama kesejahteraan penduduk di suatu wilayah, semakin tinggi tingkat kemiskinan mencerminkan tingkat kesejahteraan yang semakin memburuk dan sebaliknya semakin rendah tingkat kemiskinan mencerminkan kesejahteraan penduduk yang semakin membaik.

Indonesia termasuk negara berkembang yang banyak menyediakan lapangan pekerjaan di berbagai sektor seperti di sektor industri, sektor ekonomi, sektor pertanian dan perikanan, dan juga luasnya lahan yang terdapat di Indonesia bisa dimanfaatkan untuk berbagai kegiatan usaha yang merupakan unsur penting dalam kehidupan manusia sebagai ruang maupun sumber daya, karena sebagian besar kehidupan manusia tergantung pada lahan yang dapat di pakai sebagai sumber penghidupan, yaitu dengan mencari nafkah melalui usaha tertentu selain sebagai pemukiman. Kekayaan Indonesia berupa sumber daya perikanan yang sangat luas menjadi modal dasar dalam pembangunan nasional sekaligus memiliki potensi yang sangat besar bagi pembangunan kelautan dan perikanan. Perkembangan sektor perikanan di Indonesia saat ini semakin membaik dan 
menjadi nomor satu di Asia Tenggara, dengan ekspor perikanan Indonesia naik 5\% sedangkan impor ikan justru turun $70 \%$.

Dari sisi produksi, pada tahun 2017 produksi perikanan nasional sebesar 23,26 juta ton. Dari jumlah itu, produksi perikanan tangkap sebanyak 6,04 juta ton dan produksi perikanan budidaya sebanyak 17,22 juta ton. Dari total produksi perikanan budidaya, jumlah budidaya ikan dalam kolam air tawar menyumbangkan angka hingga 1,1 juta ton. Sisanya adalah budidaya tambak air payau, budidaya di laut, budidaya dalam keramba dan budidaya jaring apung. Kenaikan produksi budidaya ikan dalam kolam air tawar cukup pesat yaitu 11 persen setiap tahun. Hal ini menunjukkan adanya keinginan yang besar di masyarakat untuk mengembangkan usaha budidaya ikan air tawar. Tentunya pertumbuhan produksi ini mengacu pada permintaan pasar yang terus meningkat (KKP, 2016).

Bengkulu sebagai salah satu kawasan bahari di Indonesia mempunyai potensi sumberdaya ikan yang berlimpah dengan jenis ikan yang beragam. Namun konsumsi ikan di Provinsi Bengkulu masih relatif tidak stabil. Karena itulah, kegiatan Gemar Makan Ikan (GEMARIKAN) dan Forum Peningkatan Konsumsi Ikan (FORIKAN) dibuat untuk meningkatkan konsumsi ikan. Diharapkan dengan adanya peningkatan konsumsi ikan akan berdampak pada meningkatnya pemanfaatan dan pendayagunaan potensi perikanan di Provinsi Bengkulu.

Bengkulu Utara merupakan salah satu dari sepuluh kabupaten yang ada di Provinsi Bengkulu. Kabupaten Bengkulu Utara terletak di kawasan pesisir pantai barat sumatera dengan ibukotanya Arga Makmur. Kabupaten Bengkulu Utara merupakan penghasil perikanan air tawar di Provinsi Bengkulu. $40 \%$ total produksi ikan air tawar Provinsi Bengkulu adalah dari Bengkulu Utara. Sentra perikanan di Bengkulu Utara adalah di Kecamatan Padang Jaya dan telah ditetapkan sebagai Mina Politan perikanan air tawar.

Kabupaten Bengkulu Utara sebagai salah satu sentra produksi perikanan dengan produksi yang terus meningkat setiap tahunnya, diharapkan mampu mengurangi kemiskinan di Kabupaten Bengkulu Utara. Kemiskinan merupakan salah satu indikator dari tingkat kesejahteraan rumah tangga, karena kesejahteraan rumah tangga pada dasarnya adalah rumah tangga yang telah dapat memenuhi kebutuhan dasar (basic needs) secara minimal (BKKBN 2002). Kemiskinan adalah suatu kondisi dimana seseorang tidak mampu memenuhi kebutuhan dasar (basic needs) minimum baik untuk makanan maupun bukan makanan (Badan Pusat Statistik 2002). Jumlah penduduk miskin di Kabupaten Bengkulu Utara pada tahun 2017 adalah sebesar 13,11 \% dengan jumlah 38.970 jiwa. Menurut Badan Koordinasi Keluarga Berencana (BKKBN) keluarga dikatakan miskin (pra sejahtera) jika belum dapat memenuhi kebutuhan dasarnya secara minimal, seperti kebutuhan melaksanakan agama, pangan, sandang, papan dan kesehatan. Kenaikan BBM (bahan bakar minyak) mengakibatkan penurunan daya beli dan bertambahnya pengeluaran baik untuk konsumsi makanan maupun bukan makanan, yang pada gilirannya akan menambah jumlah keluarga prasejahtera baru (BKKBN 2002).

Kecamatan Padang Jaya merupakan satu dari delapan belas kecamatan yang ada di Kabupaten Bengkulu Utara. Kecamatan Padang Jaya merupakan kawasan mina politan yang dititik beratkan pada kemajuan sektor perikanan dan sudah ditetapkan oleh pemerintah Kabupaten Bengkulu Utara sebagai sentra produksi perikanan budidaya ikan nila dan jumlah produksi budidaya ikan nila di Kecamatan Padang Jaya pada tahun 2016 sebesar 3183.80 ton dan pada tahun 2017 sebesar 3534.02 ton.

Desa Sido Luhur merupakan salah satu desa yang ada di Kecamatan Padang Jaya, yang merupakan pemekaran dari Desa Marga Sakti. Desa Sido Luhur merupakan sentra perikanan budidaya ikan nila. Jumlah penduduk di Desa Sido Luhur sebanyak 425 Kartu Keluarga (KK) yang berjumlah 
1.354 jiwa, dari jumlah tersebut yang bekerja sebagai pembudidaya ikan nila sebanyak 315 kepala keluarga yang dijadikan sebagai sumber mata pencaharian utama.

Dari hasil pra penelitian yang dilakukan tingkat kesejahteraan di Desa Sido Luhur saat ini sedang mengalami penurunan atau dalam kondisi tidak baik. Permasalahan yang dihadapi oleh masyarakat Desa Sido Luhur khususnya yang bekerja sebagai pembudidaya ikan nila saat ini yaitu menurunnya produksi ikan nila dikarenakan sulitnya mendapatkan pakan ikan (pelet) sehingga harga pakan ikan (pelet) mengalami kenaikan dari harga Rp. 280.000/karung saat ini menjadi Rp. 315.000/karung. Selain harga pakan ikan yang melonjak naik, harga ikan nila justru mengalami penurunan dengan harga normal Rp.19.000/kg menjadi Rp. 17.000/kg, sehingga menyebabkan pendapatan masyarakat pembudidaya ikan nila di Desa Sido Luhur mengalami penurunan, masyarakat yang biasanya mampu untuk memenuhi kebutuhan diluar kebutuhan pokok seperti biaya pendidikan dan kesehatan kini hanya mampu untuk memenuhi kebutuhan pokok keluarga saja, sehingga tingkat kesejahteraan pembudidaya ikan nila di Desa Sido Luhur saat ini penting dipelajari dengan melihat tingkat pendapatan, tingkat pengeluaran dan kondisi sosial ekonomi rumah tangga pembudidaya ikan nila tersebut.

\section{LANDASAN TEORI}

\section{Kesejahteraan Petani}

Kesejahteraan masyarakat menunjukkan ukuran hasil pembangunan masyarakat dalam mencapai kehidupan yang lebih baik meliputi : pertama, peningkatan kemampuan dan pemerataan distribusi kebutuhan dasar seperti makanan, perumahan, kesehatan dan perlindungan. Kedua, peningkatan tingkat kehidupan, tingkat pendapatan, pendidikan yang lebih baik, dan peningkatan atensi terhadap budaya dan nilai-nilai kemanusiaan, dan ketiga, memperluas skala ekonomi dan ketersediaan pilihan sosial (Stephen C. Smit 2006).

Teori kemakmuran Adam Smith memaparkan tentang bagaimana mengelola perekonomian suatu Negara dengan cara melaksanakan persaingan bebas tanpa campur tangan pemerintah. Disertai dengan adanya pembagian kerja dan pengalokasian sumber daya yang dilakukan secara efisien, dengan menjalankkan sistem ekonomi liberal (bebas), maka pertumbuhan ekonomi dapat dicapai dengan maksimum, pertumbuhan ekonomi dapat dicapai dengan memperhatikan pertumbuhan penduduk dan pertumbuhan output total.

Pertumbuhan output (tingkat produksi) berupa barang dan jasa dipengaruhi oleh sumber alam, tenaga kerja, dan jumlah persediaan barang. Agar pertumbuhan output dapat meningkat, maka sumber-sumber alam harus dikelola oleh tenaga kerja dengan menggunakan barang modal. Sumber-sumber alam menjadi sangat vital dalam menentukan pertumbuhan ekonomi, karena sumber-sumber alam akan menjadi batas maksimum output jika dimanfaatkan secara maksimum. Sumber-sumber alam mencapai batas maksimum ketika dikerjakan oleh tenaga kerja yang memiliki kehandalan dengan menggunakan barang modal yang cukup.

Pandangan-pandangan yang disampaikan dalam teori pertumbuhan ekonomi Adam Smith, yaitu :

1. Setiap individu bebas melakukan kegiatan ekonomi agar dapat memaksimalkan kesejahteraan secara agregat atau keseluruhan. Secara prinsip individu-individu yang mengetahui akan kebutuhannya, bukan orang lain dan bukan pula pemerintah. Dalam perekonomian ini ada kekuatan yang tidak Nampak (invisible hand) yang menyebabkan perekonomian akan memperlakukan individu sesuai dengan harapannya.

2. Pembagian kerja akan meningkatkan daya produktivitas tenaga kerja akibat adanya peningkatan keterampilan dan penemuan mesin yang hemat tenaga kerja. Secara keseluruhan, hal ini akan menghemat waktu produksi. 
3. Proses akumulasi (penumpukan) modal meningkat seiring terjadinya peningkatan tabungan. Tabungan merupakan sumber utama penyediaan dana untuk investasi. Tabungan akan semakin tinggi ketika pendapatan tinggi, dengan kondisi konsumsi relatif tetap. Ketika tabungan tinggi, maka penyediaan modal investasi semakin tinggi.

4. Tingkat suku bunga akan semakin menurun ketika kemakmuran, kesejahteraan, dan jumlah penduduk semakin meningkat. Tingkat suku bunga rendah menyebabkan biaya investasi dan produksi menjadi lebih murah. Penduduk bertambah menyebabkan cadangan modal bertambah.

5. Proses pertumbuhan bersifat akumulatif. Peningkatan satu sektor ekonomi dapat meningkatkan sektor ekonomi lainnya. Ada rantai kebutuhan dan kepentingan, peningkatan di bidang pertanian dapat meningkatkan bidang industri dan bidang niaga dan seterusnya, sampai terjadi kelangkaan sumber daya sehingga perekonomian mengalami kondisi stasioner.

\section{Kemiskinan}

Menurut Badan Pusat Statistik (2002) kemiskinan adalah suatu keadaan dimana seseorang tidak mampu memenuhi kebutuhan dasar (basic needs) minimum baik untuk makanan maupun untuk bukan makanan. Kemiskinan disebabkan oleh terbatasnya sumber daya yang dimiliki atau dimanfaatkan oleh keluarga untuk memenuhi kebutuhan dasarnya. Keterbatasan itu berkaitan erat dengan rendahnya tingkat pendidikan.

Garis kemiskinan adalah besarnya nilai pengeluaran (dalam rupiah) untuk memenuhi kebutuhan dasar minimum baik untuk makanan dan bukan makanan. Nilai garis kemiskinan mengacu pada kebutuhan minimum 2.100 kilo kalori per kapita per hari ditambah dengan kebutuhan dasar seseorang yang meliputi kebutuhan dasar untuk pangan, sandang, sekolah, transportasi, serta kebutuhan rumah tangga dan individu-individu yang mendasar lainnya (BPS 2002).

\section{METODE PENELITIAN}

Jenis penelitian yang digunakan dalam penelitian ini adalah deskriptif. Menurut Trunes dalam Umar (2005:81), "penelitian deskriptif adalah penelitian yang bermaksud untuk menggambarkan sifat sesuatu yang tengah berlangsung pada saat riset (penelitian) dilakukan dan dilaksanakan sebab-sebab dari suatu gejala tertentu". Penelitian ini bertujuan untuk menyelidiki tingkat kesejahteraan pembudidaya ikan nila yang ada di Desa Sido Luhur, Kecamatan Paang Jaya Kabupaten Bengkulu Utara. Sumber data yang digunakan dalam penelitian ini yaitu menggunakan Data Primer dan Data Sekunder, dimana Data Primer merupakan data yang dikumpulkan sendiri oleh perorangan atau suatu organisasi langsung, yang langsung terjun ke lokasi dengan bertemu objeknya (Supranto, 2003). Data Primer ini menggunakan daftar pertanyaan yang telah dipersiapkan terlebih dahulu dalam bentuk kuisioner serta wawancara secara langsung sesuai data yang ingin diperoleh dalam penelitian ini.

Analisis data bertujuan untuk menyederhanakan data dalam bentuk yang lebih mudah dipahami. Data yang diperoleh diolah dan di analisis secara deskriptif setelah melalui proses editing, coding dan tabulating. Analisis data yang digunakan dalam penelitian ini meliputi :

\section{a. Karakteristik Pembudidaya Ikan Nila}

Untuk mengetahui karakteristik pembudidaya ikan nila digunakan metode analisis deskriptif kualitatif, dimana yang menjadi karakteristik pembudidaya ikan nila yaitu: umur adalah usia pembudidaya ikan nila atau kepala keluarga yang dihitung dalam tahunan. Tingkat pendidikan adalah tingkat pendidikan formal tertinggi yang ditempuh oleh pembudidaya ikan nila dengan kategori SD atau sederajat, SMP atau sederajat, dan SMA atau sederajat. Pengalaman usaha adalah lamanya waktu yang sudah dijalani oleh pembudidaya ikan nila melakukan usaha budidaya ikan 
nila (diukur dalam tahun). Jumlah anggota rumah tangga adalah keseluruhan yang mendiami suatu rumah. Satuan pengukurannya adalah orang. Luas lahan adalah ukuran lahan yang digarap atau dikelola pembudidaya ikan nila untuk digunakan sebagai tempat membudidayakan ikan nila.

Dalam penelitian ini data yang telah dikumpulkan selanjutnya dianalisa menggunakan statistik sederhana yang dilakukan meliputi pencarian rata-rata, persentase dan frekuensi serta tabulasi silang antara tingkat kesejahteraan dengan karakteristik responden. Data dikelompokkan berdasarkan jenisnya yang akan dianalisa kemudian dimasukkan dalam tabel sesuai dengan keperluan selanjutnya. Langkah-langkah dalam menyusun data dan alat analisis meliputi membuat kategori data berdasarkan karakteristik responden seperti: umur, jumlah tanggungan, tingkat pendidikan, luas kolam, dan pekerjaan lain pembudidaya ikan nila, kemudian dengan mengkategorikan berdasarkan kriteria BKKBN tahun 2015.

\section{b. Pendapatan Usaha Budidaya Ikan Nila}

Pendapatan usaha budidaya ikan nila diperoleh dari selisih antara total penerimaan usaha dengan total biaya produksi dalam satu tahun.

Analisis pendapatan dirumuskan sebagai berikut :

Dimana :

$$
\begin{aligned}
& \pi=\text { Pendapatan Usaha } \\
& \pi=\mathrm{TR}-\mathrm{TC} \\
& \mathrm{TR}=\text { Total Revenue (penerimaan) } \\
& \mathrm{TC}=\text { Total Cost (biaya) }
\end{aligned}
$$

Pendapatan rumah tangga dihitung dengan menggunakan rumus:

$$
R t=R_{p}+R_{n p}
$$

Dimana : $\quad \mathrm{Rt}=$ Total pendapatan rumah tangga

$\mathrm{R}_{\mathrm{p}}=$ Pendapatan dari usaha perikanan

$\mathrm{R}_{\mathrm{np}}=$ Pendapatan dari usaha non perikanan

c. Tingkat Kesejahteraan

Untuk mengetahui tingkat kesejahteraan rumah tangga pembudidaya ikan nila di Desa Sido Luhur, maka peneliti menggunakan metode statistik sederhana. Adapun indikator variabel yang akan dideskripsikan adalah: pendidikan, aset, sandang, pangan, papan dan sosial lainnya.

\section{HASIL DAN PEMBAHASAN}

\section{Deskripsi Kesejahteraan Rumah Tangga Pembudidaya Ikan Nila}

\section{Pengeluaran}

Pengeluaran rumah tangga dibedakan menjadi dua kelompok, yaitu pengeluaran rumah tangga untuk makanan atau konsumsi dan pengeluaran rumah tangga untuk non makanan. Pengeluaran untuk makanan antara lain pengeluaran untuk bahan konsumsi, yaitu bahan makanan dan minuman sehari-hari. Pengeluaran untuk non makanan antara lain untuk biaya kesehatan, biaya sekolah (pendidikan), biaya transportasi, pembayaran rekening listrik, telepon, hiburan, air, dan iuran RT yang dibayar setiap bulannya. Pengeluaran pembudidaya ikan nila di Desa Sido Luhur, Kecamatan Padang Jaya, Kabupaten Bengkulu Utara untuk memenuhi kebutuhan setiap bulannya, dapat dilihat pada Tabel 1: 
Tabel 1 Pengeluaran Pembudidaya Daya Ikan Nila Desa Sido Luhur

\begin{tabular}{cccc}
\hline No & PengeluaranPerbulan (Rp) & Jumlah Responden (orang) & $\begin{array}{c}\text { Persentase } \\
(\%)\end{array}$ \\
\hline 1. & $1.500 .000-2.500 .000$ & 16 & 21,33 \\
2. & $2.600 .000-3.500 .000$ & 41 & 54,67 \\
3. & $3.600 .000-4.500 .000$ & 11 & 14,67 \\
4. & $>4.500 .000$ & 7 & 9,33 \\
\hline & Jumlah & 75 & 100 \\
\hline
\end{tabular}

Sumber : Hasil Penelitian 2019

Berdasarkan Tabel 1 dapat diketahui bahwa pengeluaran pembudidaya ikan nila yang paling banyak antara 2.600.000 - 3.500.000 per bulan sebanyak 41 responden $(54,67 \%)$, dan pengeluaran pembudidaya ikan nila yang paling sedikit antara lebih dari 4.500 .000 sebanyak 7 responden $(9,33 \%)$, sehingga dapat disimpulkan bahwa rata-rata pengeluaran pembudidaya ikan nila di Desa Sido Luhur yaitu sebesar Rp 3.029.627 perbulan.

\section{Pangan}

Pangan merupakan kebutuhan dasar yaitu dilihat dari berapa kali makan dalam satu hari dan berapa kali makan daging, ikan, atau telur dalam satu minggu, dapat dilihat pada Tabel 4.2:

Tabel 2 Pangan Pembudidaya Ikan Nila Desa Sido Luhur

\begin{tabular}{clc}
\hline No & \multicolumn{1}{c}{ Pangan } & Jumlah Responden (Orang) \\
\hline 1. & Makan 3 kali sehari & 44 \\
2. & Makan 2 kali sehari & 31 \\
3. & Daging 1 kali seminggu & 29 \\
4. & Ikan 2 kali seminggu & 52 \\
5. & Telur 2 kali seminggu & 51 \\
\hline
\end{tabular}

Sumber : Hasil Penelitian 2019

Berdasarkan Tabel 2 dapat diketahui bahwa pembudidaya ikan nila di Desa Sido Luhur, Kecamatan Padang Jaya, Kabupaten Bengkulu Utara telah memenuhi kebutuhan dasarnya, yang terbanyak makan 3 kali sehari yaitu sebanyak 44 responden $(58,67 \%)$ maka dari segi pangan perhari pembudidaya ikan nila masuk dalam pengelompokan keluarga sejahtera 1 . Dilihat dari segi makan daging, ikan, atau telur dalam satu minggu yang terbanyak yaitu mengkonsumsi ikan sebanyak 52 responden $(69,33 \%)$, maka pembudidaya ikan nila di Desa Sido Luhur dilihat dari frekuensi makan daging, ikan, atau telur dalam satu minggu masuk dalam kategori keluarga sejahtera II.

\section{Sandang}

Sandang adalah jumlah pakaian baru yang diperoleh para pembudidaya ikan nila di Desa Sido Luhur dalam satu tahun, dapat dilihat pada Tabel 3: Berdasarkan Tabel 3 dapat diketahui bahwa pembudidaya ikan nila di Desa Sido Luhur, Kecamatan Padang Jaya, Kabupaten Bengkulu Utara sudah memenuhi kriteria keluarga sejahtera II menurut BKKBN, yaitu memperoleh paling kurang satu stel pakaian dalam satu tahun. Berdasarkan hasil penelitian ini menunjukkan bahwa yang terbanyak adalah dua stel pakaian dalam setahun yaitu 47 responden $(62,67 \%)$.

Tabel 3 Jumlah Pakaian Baru Pembudidaya Ikan Nila Dalam Satu Tahun. 


\begin{tabular}{ccc}
\hline No & \multicolumn{2}{c}{ Pakaian (Dalam Satu } \\
Tahun) & Jumlah Responden (orang) \\
\hline 1. & 1 stel & 6 \\
2. & 2 stel & 47 \\
3. & 3 stel & 15 \\
4. & 4 stel & 7 \\
\hline
\end{tabular}

Sumber : Hasil Penelitian 2019

\section{Papan}

Papan adalah keadaan tempat tinggal yang ditempati oleh pembudidaya ikan nila di Desa Sido Luhur, Kecamatan Padang Jaya, Kabupaten Bengkulu Utara, berdasarkan hasil penelitian yang dilakukan maka diketahui bahwa semua pembudidaya ikan nila di Desa Sido Luhur telah memenuhi kriteria berdasarkan BKKBN, maka dapat dikategorikan dalam kelompok keluarga sejahtera I, dimana kategori layak menurut BKKBN yaitu rumah sudah ada lantai semen dan dinding semi permanen atau semen, lantai semen atau keramik.

\section{Sosial Lainnya}

Sosial lainnya yaitu adanya upaya untuk meningkatkan ilmu agama dan menjalankan ibadah menurut kepercayaan masing-masing, serta adanya keinginan untuk aktif dalam kegiatan masyarakat, berdasarkan hasil penelitian yang dilakukan di Desa Sido Luhur semua responden dari pembudidaya ikan nila telah meningkatkan ilmu agamanya yaitu dengan mengikuti pengajian, belajar mengaji, dan sholat, dapat dikategorikan ke dalam keluarga sejahtera III.

Tabel 4 Kegiatan Masyarakat Pembudidaya Ikan Nila Di Desa Sido Luhur.

\begin{tabular}{clc}
\hline No & \multicolumn{1}{c}{ Sosial Lainnya } & Jumlah Responden (orang) \\
\hline 1. & Mengikuti kegiatan masyarakat & 38 \\
2. & Tidak mengikuti kegiatan masyarakat & 37 \\
\hline
\end{tabular}

Sumber : Hasil Penelitian 2019

Berdasarkan Tabel 4 dapat diketahui bahwa pembudidaya ikan nila di Desa Sido Luhur, Kecamatan Padang Jaya, Kabupaten Bengkulu Utara masuk dalam kategori keluarga sejahtera III, karena sebagian besar pembudidaya ikan nila di Desa Sido Luhur telah mengikuti kegiatan masyarakat yaitu yang terbanyak adalah 38 responden $(50,67 \%)$. Kegiatan masyarakat yaitu kegiatan sosial yang diikuti oleh pembudidaya ikan nila seperti kegiatan sosial yang diikuti pembudidaya ikan nila seperti kegiatan RT, PKK, Karang taruna.

\section{Kepemilikan Aset}

Kepemilikan asset pembudidaya ikan nila di Desa Sido Luhur, Kecamatan Padang Jaya, Kabupaten Bengkulu Utara seperti status kepemilikan tempat tinggal, luas bangunan dan luas tanah tempat tinggal, kepemilikan kendaraan, alat elektronik serta kepemilikan hewan ternak. Dalam pengukuran kesejahteraan pembudidaya ikan nila status dan fasilitas di dalam tempat tinggal itu sendiri.

Tabel 5 Kepemilikan Aset Pembudidaya Ikan Nila Desa Sido Luhur

\begin{tabular}{crlc}
\hline No & & Jenis Aset & Jumlah Responden (orang) \\
\hline 1. & Rumah & & 75 \\
2. & Kendaraan & Pribadi & a. \\
& Mobil & 3 \\
\hline
\end{tabular}




\begin{tabular}{rrrr}
\hline No & & Jenis Aset & Jumlah Responden (orang) \\
\hline \multicolumn{3}{r}{ b. Motor } & 75 \\
& Elektronik & 28 \\
a. Mesin cuci & 74 \\
b. Kulkas & 75 \\
c. TV & \\
4. Ternak & 1 \\
& a. Sapi & 14 \\
& b. Ayam & 3 \\
& c. Itik
\end{tabular}

Sumber : Hasil Penelitian 2019

Berdasarkan Tabel 5 dapat diketahui bahwa status kepemilikan tempat tinggal pembudidaya ikan nila di Desa Sido Luhur berdasarkan hasil penelitian yang dilakukan kepada 75 responden pembudidaya ikan nila sudah memiliki tempat tinggal sendiri semuanya, dengan luas bangunan rata-rata yaitu $9 \mathrm{~m}^{2} \times 11 \mathrm{~m}^{2}$ dan luas tanah rata-rata $10 \mathrm{~m}^{2} \times 15 \mathrm{~m}^{2}$. Komponen yang menentukan kemudahan fasilitas transportasi adalah ongkos atau biaya transportasi, dan kepemilikan kendaraan. Sebanyak 3 responden $(4 \%)$ pembudidaya ikan nila yang mempunyai mobil, dan semuanya pembudidaya ikan nila sudah memiliki motor, hal ini berarti semua responden dari pembudidaya ikan nila di Desa Sido Luhur sudah mempunyai kendaraan sendiri.

Berdasarkan hasil penelitian fasilitas elektronik yang dimiliki oleh pembudidaya ikan di Desa Sido Luhur, Kecamatan Padang Jaya, Kabupaten Bengkulu Utara, dimana semua responden pembudidaya ikan nila sudah memiliki TV dengan berbagai merk, memiliki lemari pendingin sebanyak 72 responden $(96 \%)$, dan 28 responden $(37,33 \%)$ yang hanya memiliki mesin cuci, hal ini berarti masih banyak pembudidaya ikan nila yang mencuci secara manual.

Hewan ternak yang dimiliki pembudidaya ikan nila di Desa Sido Luhur, Kecamatan Padang Jaya, Kabupaten Bengkulu Utara adalah sapi 3 ekor, 145 ekor ayam, dan itik sebanyak 42 ekor. Pembudidaya ikan nila memiliki hewan ternak sebanyak 1 orang $(1,33 \%)$ mempunyai sapi, 14 orang $(18,67 \%)$ mempunyai ayam, dan 3 orang (4\%) yang mempunyai itik. Maka dapat disimpulkan pembudidaya ikan nila di Desa Sido Luhur, Kecamatan Padang Jaya, Kabupaten Bengkulu Utara berada dalam pengelompokan keluarga sejahtera III.

\section{Fasilitas Kesehatan}

Fasilitas kesehatan yaitu fasilitas kesehatan pemerintah yang digunakan pembudidaya ikan nila di Desa Sido Luhur, Kecamatan Padang Jaya, Kabupaten Bengkulu Utara. Berdasarkan hasil penelitian bahwa sebanyak 6 orang $(8 \%)$ pembudidaya ikan nila menggunakan fasilitas BPJS kesehatan, 11 orang $(14,67 \%)$ pembudidaya ikan nila yang memperoleh bantuan dana kesehatan dari pemerintah berupa KIS (Kartu Indonesia Sehat), 3 orang (4\%) pembudidaya ikan nila yang memperoleh raskin dari pemerintah dan sebanyak 56 orang $(74,67 \%)$ pembudidaya ikan nila yang tidak menggunakan fasilitas kesehatan yang disediakan pemerintah. Hal ini menunjukkan bahwa kurangnya pengetahuan pembudidaya ikan nila di Desa Sido Luhur, Kecamatan Padang Jaya, Kabupaten Bengkulu Utara akan pentingnya pembayaran dan penggunaan fasilitas kesehatan yang telah disediakan oleh pemerintah.

\section{Pembahasan Kesejahteraan Berdasarkan BKKBN}

Keluarga sejahtera adalah keluarga yang telah dapat memenuhi kebutuhan dasarnya (basic needs) secara minimal. Pengkategorian keluarga sejahtera menurut BKKBN Tahun 2015 dibagi menjadi empat, yaitu : keluarga pra sejahtera, keluarga sejahtera I (KS I), keluarga sejahtera II (KS II), keluarga sejahtera III (KS III). Tahapan keluarga sejahtera berdasarkan BKKBN dapat disajikan 
pada Tabel 4.14 pengelompokan pembudidaya ikan nila, berdasarkan penelitian yang dilakukan di Desa Sido Luhur semua responden tidak ada yang termasuk kedalam golongan keluarga pra sejahtera, karena sudah mampu memenuhi kebutuhan dasarnya.

Pengelompokan keluarga sejahtera I apabila sudah memenuhi kriteria, seperti, a.) Pada umumnya anggota keluarga makan dua kali sehari atau lebih, b.) Anggota keluarga memiliki pakaian yang berbeda untuk dirumah, bekerja, sekolah dan bepergian, c.) Rumah yang ditempati mempunyai atap, lantai, dan dinding yang layak, d.) Bila anggota keluarga sakit dibawa ke sarana kesehatan, e.) Semua anak 7-15 tahun dalam keluarga bersekolah. Dalam penelitian ini terdapat 17 responden $(22,67 \%)$ yang masuk dalam kategori keluarga sejahtera I, karena sudah memenuhi kebutuhan dasar seperti kriteria menurut BKKBN diatas.

Pengelompokan keluarga sejahtera II apabila sudah memenuhi kriteria, seperti, a.) Pada umumnya anggota keluarga melaksanakan ibadah sesuai dengan agama dan kepercayaannya masing-masing, b.) Paling kurang sekali seminggu anggota keluarga makan daging, c.) Seluruh anggota keluarga paling kurang memperoleh satu stel pakaian baru dalam satu tahun, d.) Luas lantai rumah paling kurang $8 \mathrm{~m}^{2}$ untuk tiap penghuni rumah, e.) Ada seorang atau lebih anggota keluarga yang bekerja untuk memperoleh penghasilan. Dalam penelitian ini terdapat 25 responden $(33,33 \%)$ yang masuk dalam kategori keluarga sejahtera II, karena sudah memenuhi kebutuhan-kebutuhan seperti kriteria BKKBN diatas.

Pengelompokan keluarga sejahtera III apabila sudah memenuhi kriteria, seperti, a.) Keluarga berupaya meningkatkan pengetahuan agama, b.) Sebagian dari penghasilan keluarga ditabung dalam bentuk uang maupun barang, c.) Keluarga sering ikut dalam kegiatan masyarakat dilingkungan tempat tinggalnya, d.) Keluarga memperoleh informasi dari surat kabar, majalah, radio atau tv. Dalam penelitian ini terdapat 33 responden $(44 \%)$ yang masuk dalam kategori keluarga sejahtera III, karena sudah memenuhi semua kriteria menurut BKKBN. Untuk lebih jelasnya dapat dilihat pada Tabel 6 .

Tabel 6 Tahapan Keluarga Sejahtera Berdasarkan BKKBN

\begin{tabular}{llcc}
\hline No & Kategori & Jumlah (Responden) & Persentase (\%) \\
\hline 1. & Keluarga Sejahtera III (KS III) & 33 & 44 \\
2. & Keluarga Sejahtera II (KS II) & 25 & 33,33 \\
3. & Keluarga Sejahtera I (KS I) & 17 & 22,67 \\
\hline & Jumlah & 75 & 100 \\
\hline
\end{tabular}

Sumber : Hasil Penelitian 2019

Berdasarkan Tabel 6 menunjukkan bahwa pembudidaya ikan nila di Desa Sido Luhur, Kecamatan Padang Jaya, Kabupaten Bengkulu Utara dalam penelitian ini dari 75 sampel sebanyak 33 orang (44\%) termasuk keluarga sejahtera III (KS III), 25 orang $(33,33 \%)$ termasuk keluarga sejahtera II (KS II), 17 orang $(22,67 \%)$ termasuk kategori keluarga sejahtera I (KS I). Hal ini menunjukkan bahwa pembudidaya ikan nila di Desa Sido Luhur, Kecamatan Padang Jaya, Kabupaten Bengkulu Utara yang paling banyak masuk dalam kategori sejahtera III yaitu sebanyak 33 orang (44\%), dan yang paling sedikit masuk dalam kategori sejahtera I yaitu sebanyak 17 orang $(22,67 \%)$.

Hal ini berarti bahwa pembudidaya ikan nila di Desa Sido Luhur, Kecamatan Padang Jaya, Kabupaten Bengkulu Utara rata-rata telah dapat memenuhi kebutuhan dasarnya (basic needs) secara minimal, seperti kebutuhan melaksanakan agama, pangan, sandang, papan dan kesehatan, selain itu juga telah dapat memenuhi kebutuhan sosial psikologisnya. Kebutuhan sosial psikologis tersebut antara lain yaitu : kebutuhan pendidikan, keluarga berencana, tempat tinggal dan transportasi, dan pembudidaya ikan nila di Desa Sido Luhur telah dapat memenuhi kebutuhan perkembangannya, seperti kebutuhan untuk menabung dan memperoleh informasi. 
Hal ini sependapat dengan penelitian yang dilakukan oleh Mulyanah (2005) yang melakukan penelitian kesejahteraan di Kabupaten Bogor Desa Bojong Jengkol Kecamatan Ciampea, dimana ia mengemukakan bahwa umur, pendidikan, jumlah tanggungan dan luas lahan mempengaruhi kesejahteraan diukur dengan melalui aspek pendapatan. Pembudidaya ikan nila di Desa Sido Luhur, Kecamatan Padang Jaya, Kabupaten Bengkulu Utara berdasarkan hasil penelitian dan diukur menurut BKKBN yaitu sebanyak 33 orang (44\%) masuk dalam kategori keluarga sejahtera III (KS III).

Secara umum pembudidaya ikan nila di Desa Sido Luhur, Kecamatan Padang Jaya, Kabupaten Bengkulu Utara dapat dikatakan sejahtera, hal ini dikarenakan pembudidaya ikan nila secara umum sudah memenuhi kriteria menurut indicator BKKBN, karena sebagian besar sudah dapat memenuhi kebutuhan dasarnya sehari-hari, sebanyak 33 responden yang terbanyak yaitu berada pada strata sejahtera III, dan berdasarkan penelitian tidak terdapat lagi pembudidaya ikan nila yang berada kategori pra sejahtera.

\section{KESIMPULAN}

Berdasarkan hasil penelitian terhadap rumah tangga pembudidaya ikan nila di Desa Sido Luhur, Kecamatan Padang Jaya, Kabupaten Bengkulu dapat disimpulkan bahwa pembudidaya ikan nila di Desa Sido Luhur, Kecamatan Padang Jaya, Kabupaten Bengkulu Utara menurut BKKBN dianggap sudah sejahtera, jika dilihat dari karakteristik pembudidaya ikan nila umumnya dalam usia yang produktif yaitu rata-rata usia 46 tahun, pendidikan umumnya rendah yaitu sampai tingkat SLTA, jumlah tanggungan rata-rata 4 orang, dan memiliki luas kolam rata-rata 1,7 ha dengan kedalaman kolam dari $120 \mathrm{~cm}-2$ meter. Pendapatan yang diperoleh pembudidaya ikan nila ratarata $\mathrm{Rp}$ 3.452.067 per bulan dengan pengeluaran rata-rata $\mathrm{Rp} 3.029 .627$ per bulan. Berdasarkan kriteria menurut BKKBN semua pembudidaya ikan nila di Desa Sido Luhur tidak ada yang berada dalam kategori pra sejahtera karena sudah dapat memenuhi kebutuhan dasarnya seperti sandang, pangan, papan dan yang terbanyak yaitu (44\%) masuk dalam strata sejahtera III, karena sudah memenuhi kriteria BKKBN sebagai keluarga sejahtera III, selain itu juga telah mencapai kebutuhan psikologis yaitu kebutuhan pendidikan, tempat tinggal, aset, dan kegiatan sosial dalam lingkungan tempat tinggal, maka pembudidaya ikan nila di Desa Sido Luhur, Kecamatan Padang Jaya, Kabupaten Bengkulu Utara semakin dekat dengan strata sejahtera III + yaitu tingkat kesejahteraan tertinggi menurut BKKBN.

Rekomendasi untuk penelitian lanjutan yang diberikan dari hasil penelitian ini adalah, dalam penelitian ini tidak melihat bantuan dari pemerintah mengenai keberlanjutan budidaya ikan nila dan kurangnya sosialisasi dari pemerintah setempat mengenai cara budidaya ikan nila dengan kualitas ikan yang lebih bagus, dan diharapkan dapat menemukan inovasi terbaru selain dari budidaya ikan nila, budidaya ikan apa yang lebih cocok dan menguntungkan bagi masyarakat Desa Sido Luhur.

\section{DAFTAR PUSTAKA}

Badan Pusat Statistik Jakarta Pusat. 1998. Pendapatan dan Penerimaan Rumah Tangga 2003. Jakarta : BPS.

Badan Pusat Statistik Jakarta Pusat. 2002. Pendapatan dan Penerimaan Rumah Tangga 2003. Jakarta : BPS.

Badan Pusat Statistik. 2002. Survei Sosial Ekonomi Nasional (Susenas). Tahun 2010. Jakarta : BPS

Kementrian Kelautan dan Perikanan (KKP). 2016. Fishing News Books Ltd. 238 hal 
Kementrian Kelautan dan Perikanan (KKP). 2016. Fishing News Books Ltd. 230 hal

Mulyanah. 2005. Tingkat Kesejahteraan Rumah Tangga Pembudidaya Ikan di Desa Bojong Jengkol, Kecamatan Ciampea, Kabupaten Bogor. Skripsi. Fakultas Perikanan dan Ilmu Kelautan. Institut Pertanian Bogor, Bogor.

Ogunremi, Olatunji. 2016. Assessment of Awareness and Adoption of Fish Farming Technologies in Obio-Akpor Local Government Area of Rivers, Nigeria. The Journal of Agricultural Sciences Vol 11 (3) : 4-7. 3 Maret 2019, University of Ibadan, Nigeria.

Olanike, Alawode. 2016. Effect of Catfish Production on Welfare of Smallholder Farmers in Osun State, Nigeria. Journal of Agribusiness and Rural Development Vol 45 (2) : 14-17. 2 Maret 2019, University of Limpopo, South Africa.

Rosni. 2016. Analisis Tingkat Kesejahteraan Masyarakat Nelayan di Desa Dahari Selebar, Kecamatan Talawi, Kabupaten Batubara. Jurnal Unimed, Vol 09 (1) : 17. 28 Februari 2019, Universitas Negeri Medan, Sumatera Utara.

Sutawijaya dkk. 2013. Analisis Tingkat Kesejahteraaan Rumah Tangga Petani Ikan Hias Air Tawar di Kelurahan Cipedak, Kecamatan Jagakarsa, Kota Madya Jakarta Selatan. Jurnal Agribisnis. P-ISSN 1979-0058 Vol 07 (1) : 2-5. 5 Maret 2019, UIN Syarif Hidayatullah, Jakarta.

Syofian, Siregar. 2014. Metode Penelitian Kuantitatif. Jakarta : Kencana.

Tjakrawiralaksana A. 1983. Usaha Tani. Direktorat Jenderal Pendidikan Dasar dan Menengah. Jakarta : Departement Pendidikan dan Kebudayaan.

Todaro, Michael P. 2006. Pembangunan Ekonomi (edisi kesembilan, jilid 1). Jakarta:Erlangga. 